KIDDO : JURNAL PENDIDIKAN ISLAM ANAK USIA DINI

http://kiddo@iainmadura.ac.id

P-ISSN 2716-0572, E-ISSN 2716-1641

\title{
Karakteristik Pola-Pola Pengasuhan Anak Usia Dini dalam Keluarga
}

\author{
Rani Handayani ${ }^{\mathbf{1}}$ \\ UIN Sultan Syarif Kasim Riau ${ }^{1}$, Indonesia \\ Email : ranihandayani938@gmail.com
}

\begin{abstract}
This research is background in parenting given by parents to early childhood. The pattern of parenting in the family means the habits of parents, fathers and mothers, in leading, nurturing, and guiding children in the family. The purpose of this study was to determine the characteristics of parenting patterns for early childhood by parents. The method used is a literature study with the technique of collecting information from various written sources. Based on the results of research from sources obtained, it can be concluded that parenting is an interaction between children and parents during parenting. This parental attitude includes the way parents give rules, rewards and punishments, the way parents show their authority, and the way parents pay attention and respond to their children.
\end{abstract}

\author{
Keywords: \\ Patterns ; \\ Parenting ; \\ Early Childood \\ Family;
}

\footnotetext{
Peneitian ini berlatar belakang pada pola asuh yang diberikan orang tua terhadap anak usia dini. Pola asuh orang tua dalam keluarga berarti kebiasaan orang tua, ayah dan ibu, dalam memimpin, mengasuh, dan membimbing anak dalam keluarga.

\author{
Kata Kunci: \\ Pola-Pola \\ Pengasuhan; \\ Keluarga.
}

Anak Usia Dini;
} Tujuan penelitian ini adalah untuk mengetahui karakteristik pola-pola pengasuhan terhadap anak usia dini oleh orang tua. Metode yang digunakan adalah studi pustaka dengan teknik pengumpulan informasi dari berbagai sumber tertulis. Berdasarkan hasil penelitian dari sumber yang di dapat, ditarik kesimpulan bahwa pola asuh orang tua merupakan interaksi antara anak dan orang tua selama pengasuhan. Sikap orangtua ini meliputi cara orang tua memberikan aturan-aturan, hadiah maupun hukuman, cara orang tua menunjukkan otoritasnya, dan cara orang tua memberikan perhatian serta tanggapan terhadap anaknya. 
Diterima : 8 Juli 2021; Direvisi : 10 Agustus 2021; Diterbitkan: 28 Agustus 2021 http://doi.org/10.19105/kiddo.v2i2.4797

\section{Pendahuluan}

Anak usia dini adalah anak yang berada pada rentang usia 0-6 tahun. Pada usia tersebut, perkembangan terjadi sangat pesat. Oleh karena itu, usia dini dipandang sangat penting sehingga diistilahkan sebagai usia emas (golden age). Sebab pada masa ini perkembangan otak anak terjadi dengan sangat pesat yang mencapai 50\% - 80\% dari keseluruhan perkembangan usia selama hidupnya. Menurut Berk dalam Yulsyofriend (2013:1), menyatakan bahwa anak usia dini merupakan individu yang sedang menjalani proses tumbuh kembang yang pesat dan fundamental dalam keberlangsungan hidup kedepannya. Dapat dinyatakan bahwa anak usia dini merupakan pribadi yang unik, dinamik, serta memiliki rasa ingin tahu yang tinggi yang membuat setiap diri mereka berbeda dengan anak lainnya.

Setiap keluarga memiliki gaya pengasuhan yang berbeda dalam mendidik anak-anaknya. Pengasuhan yang diberikan oleh orang tua memberikan pengaruh terhadap pembentukan karakter dan perilaku anak. Karakter dan perilaku yang dibentuk sangat menentukan kematangan seseorang dalam melakukan sebuah tindakan ataupun penyelesaian masalah. Oleh sebab itu pola pengasuhan menjadi hal yang penting untuk diperhatikan.

Pendidikan orang tua memiliki pengaruh terhadap pola pengasuhan terhadap anak. Selain faktor pendidikan, faktor lain yang berpengaruh terhadap pola asuh yaitu pengalaman orang tua dalam mengasuh anak, keterlibatan orang tua dalam mengasuh anak, usia orang tua, stres yang mungkin dialami orang tua, dan hubungan antara suami istri di dalam keluarga. Pola asuh yang baik dan tepat menjadi faktor terbentuknya karakter dan perilaku terpuji pada anak.

Setiap orangtua tentunya ingin yang terbaik bagi anak-anak mereka. Keinginan ini kemudian akan membentuk pola asuh yang akan ditanamkan orangtua kepada anak-anak. Pola asuh menurut Diana Baumrind (1967), pada prinsipnya merupakan parental control yaitu bagaimana orangtua mengontrol, membimbing, dan mendampingi anak-anaknya untuk melaksanakan tugas-tugas perkembangannya menuju pada proses pendewasaan.

Anak tumbuh dan berkembang di bawah asuhan orang tua untuk beradaptasi dengan lingkungan, mengenal dunia sekitarnya, dan pola pergaulan hidup di lingkungan. Pengasuhan dan pendidikan yang baik 
dari keluarga sangat diperlukan dalam membentuk kepribadian seorang anak. Setiap keluarga memiliki pola asuh yang berbeda dalam mendidik seorang anak dan biasanya diturunkan oleh pola asuh yang diterima dari orang tua sebelumnya.

Pola asuh orang tua pada anak usia dini akan membentuk karakter ada anak, karenanya orang hendaknya memberikan stimulasi yang cukup bagi anak usia dini jikalau itu kurang akan mengakibatkan kemampuan sosialisi menjadi terlambat, maka dari itu lingkungan yang menunjang akan mendukung tumbuh kembang pada anak usia dini, proses pertumbuhan dan perkembangan seorang anak sangat pesat dan dapat berpengaruh bagi kehidupan selanjutnya. Anak pada masanya pembentukan biasanya akan di pengaruhi oleh lingkungan dalam membentuk karakter pada anak.

Peran keluarga dalam pengasuhan anak sangatlah penting karena dapat mempengaruhi dan membentuk kepribadian atau karakter anak. Karakter anak tentu saja bergantung dari pola asuh orang tua terhadap anaknya. Keluarga juga mempunyai peranan dalam pengasuhan anak yaitu mengetahui tahap-tahap perkembangan anak untuk mengasuhnya sesuai dengan bakat dan keinginan anak. Namun, pola pengasuhan ayah dan ibu mempunyai perbedaan dan hal ini tidak membuat orang tua menjadi sulit dalam mengasuh anak, melainkan menjadi suatu hal untuk melengkapi kekurangan masing-masing dalam mengasuh anak.

Pola asuh orang tua menjadi dasar pembentukan kepribadian anak. Hal ini sangat penting bagi kehidupan anak karena perkembangan anak berawal dari pola asuh kedua orang tua. Apabila cara orang tua mendidik anaknya di rumah dengan baik, maka di sekolah atau di lingkungan masyarakat anak itu pun akan berperilaku baik pula. Tapi sebaliknya apabila cara orang tua mendidik anaknya dirumah dengan kurang baik seperti lebih banyak santai, bermain, dimanjakan, maka di sekolah atau di lingkungan masyarakat yang kondisinya berbeda dengan lingkungan di keluarganya maka anak tersebut akan menjadi pemberontak, nakal, kurang sopan dan malas.

Berdasarkan uraian diatas, dapat diketahui bahwa pola asuh yang diberikan orang tua pada anak berbeda-beda yang akan dapat mempengaruhi kepribadian dan tingkah laku anak dalam berinteraksi dengan orang lain dilingkungannya. Namun tidak semua orang tua memahami hal tersebut, terkadang orang tua secara tidak sadar atau bahkan lalai dalam memberikan pengasuhan maupun kebiasaan yang tidak baik yang membuat anak mengikuti hal tersebut. Dari hasil observasi yang ditemukan, pola perilaku yang diterapkan pada anak yang bersifat relatif konsisten dari waktu ke waktu dan sangat berpengaruh besar dalam pembentukan karakteristik anak yang dampaknya akan dirasakan oleh anak baik dari segi positif atau negatif. Oleh karena itu peneliti tertarik mengangkat suatu topik permasalahan yang berkaitan dengan pengasuhan orang tua, yaitu dengan judul "Karakteristik Pola-pola Pengasuhan Anak Usia Dini dalam Keluarga". 


\section{Metode}

Metode yang digunakan dalam penelitian ini adalah studi pustaka (Literatur Research), yaitu peneliti menganalisa sumber-sumber yang berkaitan dengan topik yang diangkatkan dalam penelitian ini. Sumber yang digunakan berupa skripsi, buku, serta jurnal yang relevan dengan karakteristik pola pengasuhan yang diberikan orang tua terhadap anak pada usia dini dalam keluarga. Studi literature merupakan teknik pengumpulan data dengan menelaah sumber literature barupa buku, catatan, laporan yang berhubungan dengan permasalahan yang ingin dipecahkan. Sehingga studi yang digunakan pada penelitian ini berkaitan erat dengan pola pengasuhan yang diberikan pada anak usia dini guna untuk melihat pengasuhan anak dalam keluarga.

\section{Hasil dan Pembahasan \\ Pengertian Pola Asuh Orang Tua Dalam Keluarga}

Pola asuh orang tua dalam keluarga adalah sebuah frasa yang menghimpun empat unsur penting, yaitu pola, asuh, orang tua, dan keluarga. Pola adalah pola asuh terdiri dari dua kata, yaitu pola dan asuh. Menurut Kamus besar Bahasa Indonesia, pola berarti corak, model, sistem, cara kerja, bentuk (struktur) yang tetap. Ketika pola diberi arti bentuk/struktur yang tetap, maka hal ini semakna dengan istilah "kebiasaan". Asuh berarti mengasuh satu bentuk kata kerja yang bermakna 1) menjaga (merawat dan mendidik) anak kecil; 2) membimbing (membantu, melatih, dan sebagainya) supaya dapat berdiri sendiri; 3) memimpin (mengepalai, menyelenggarakan) suatu badan kelembagaan. Kata asuh mencakup segala aspek yang mencakup segala aspek yang berkaitan dengan pemeliharaan, perawatan, dukungan, dan bantuan sehingga orang tetap berdiri dan menjalani hidupnya secara sehat. Orang tua menurut kamus besar Bahas Indonesia adalah ayah ibu kandung, (orang tua) orang yang dianggap tua (cerdik, pandai, ahli, dan sebagainnya), orang-orang yang dihormati dan (disegani) dikampung.

Dalam konteks keluarga, tentu saja orang tua yang dimaksud adalah ayah atau ibu kandung dengan tugas dan tanggung jawab mendidik anak dalam keluarga. Keluarga merupakan suatu kesatuan yang diikat oleh adanya saling berhubungan atau interaksi dan saling mempengaruhi antara satu dengan lainnya, walaupun di antara meraka tidak terdapat hubungan darah. (Shochib, 1998:7).

Pola asuh dapat didefinisikan sebagai pola interaksi antara anak dengan orangtua yang meliputi pemenuhan kebutuhan fisik (seperti makan, minum dan lain-lain) dan kebutuhan psikologis (seperti rasa aman, kasih sayang dan lain-lain), serta sosialisasi norma-norma yang berlaku di masyarakat agar anak dapat hidup selaras dengan lingkungannya (Latifah, 2011).

Berdasarkan definisi-definisi diatas, dapat ditarik kesimpulan bahwa pola asuh adalah interaksi antara anak dan pengasuh selama pengasuhan, yang meliputi proses mengembangkan pengetahuan dan keterampilan yang sesuai untuk anak, cara mendidik dengan memberi aturan-aturan dan batasan-batasan yang diterapkan pada anak- 
anaknya, pemeliharaan, menanamkan kepercayaan, cara bergaul, sikap menciptakan suasana emosional memenuhi kebutuhan anak, memberi perlindungan, serta mengajarkan tingkah laku umum yang dapat diterima oleh masyarakat.

\section{Macam-Macam Pola Asuh}

Menurut Baumrind (dalam Santrock, 2002: 257-258) terdapat empat macam bentuk pola asuh yang diterapkan oleh masing-masing orang tua, bentuk-bentuk pola asuh itu adalah, pola asuh demokratis, pola asuh otoriter, pola asuh permisif dan pola asuh penelantar.

Pola Asuh Demokratis adalah pola asuh yang memprioritaskan kepentingan anak, akan tetapi tidak ragu-ragu mengendalikan mereka. Orang tua dengan pola asuh ini bersikap rasional, selalu mendasari tindakannya pada rasio atau pemikiran-pemikiran. Orang tua tipe ini juga bersikap realistis terhadap kemampuan anak, tidak berharap yang berlebihan yang melampaui kemampuan anak. Orang tua tipe ini juga memberikan kebebasan kepada anak untuk memilih dan melakukan suatu tindakan, dan pendekatannya kepada anak bersifat hangat.

Anak yang diasuh dengan pola asuh demokratis akan menghasilkan karakter anak-anak yang mandiri, dapat mengontrol diri, mempunyai hubungan baik dengan teman-temannya, mampu menghadapi stres, mempunai minat terhadap hal-hal yang baru, dan kooperatif terhadap oranglain. Dan cenderung mengungkapkan agresivitasnya dalam tindakan-tindakan konstruktif atau dalam bentuk kebencian yang sifatnya sementara saja. Pola asuh demokratis tampaknya lebih kondusif dalam pendidikan karakter anak. Hal ini dapat dilihat dari hasil penelitian yang dilakukan oleh Baumrind yang menunjukkan bahwa orangtua yang demokratis lebih mendukung perkembangan anak terutama dalam kemandirian dan tanggung jawab.

Pola asuh Otoriter, adalah pola asuh dimana orangtua memaksakan anak untuk selalu memenuhi apa yang orang tua harapkan dan inginkan. Dan orangtua memasang beberapa peraturan dimana anak tersebut wajib menaati peraturan tersebut dan akan memberi hukuman atau ancaman apabila sang anak melanggarnya atau tidak mematuhi hukuman tersebut. Misalnya saat sang anak tidak tidur siang, maka orangtua akan marah dan tidak memberikan uang jajan.

Orangtua yang menggunakan pola asuh otoriter biasanya cenderung orang yang keras, kolot, tidak mengenal kompromi, dan biasanya komunikasi yang digunakan bersifat satu arah. Artinya orangtua tidak memperdulikan pendapat anak dan tidak memperlukan feed back dari anaknya untuk mengerti tentang anak tersebut. Pola asuh otoriter mempunyai ciri orangtua membuat semua keputusan, anak harus tunduk, patuh, dan tidak boleh bertanya. Kekuasaan orangtua dominan, Anak tidak diakui sebagai pribadi, Kontrol terhadap tingkah laku anak sangat ketat, membatasi perilaku kasih sayang, sentuhan, dan kelekatan emosi orangtua anak sehingga antara orang tua dan anak seakan memiliki dinding pembatas yang memisahkan "si otoriter" (orang tua) dengan "si patuh" (anak). 
Pola asuh Permisif, pola asuh ini memberikan pengawasan yang sangat longgar. Memberikan kesempatan pada anaknya untuk melakukan sesuatu tanpa pengawasan yang cukup darinya. Mereka cenderung tidak menegur atau memperingatkan anak apabila anak sedang dalam bahaya, dan sangat sedikit bimbingan yang mereka berikan. Namun orang tua tipe ini biasanya bersifat hangat, sehingga seringkali disukai oleh anak. Anak tidak dituntut untuk bertanggung jawab dan tidak banyak dikontrol oleh orang tua. Pola asuh permisif memandang anak sebagai seorang pribadi dan mendorong mereka untuk tidak berdisiplin dan anak diperbolehkan untuk mengatur tingkah lakunya sendiri. Dengan pola asuh seperti ini anak mendapat kebebasan sebanyak mungkin dari keluarganya.

Pola asuh Penelantar, orang tua tipe ini pada umumnya memberikan waktu dan biaya yang sangat minim pada anak-anaknya. Waktu mereka banyak digunakan untuk keperluan pribadi mereka, seperti bekerja, dan juga kadangkala biaya pun dihemat-hemat untuk anak mereka. Termasuk dalam tipe ini adalah perilaku penelantar secara fisik dan psikis pada ibu yang depresi. Ibu yang depresi pada umumnya tidak mampu memberikan perhatian fisik maupun psikis pada anak-anaknya.

Dari keempat macam pola asuh tersebut bentuk pola asuh demokrasilah pola asuh paling baik diterapkan oleh orang tua dalam mengasuh anak-anaknya (Jannah, 2012), karena pola asuh ini membentuk perilaku anak yang memiliki rasa percaya diri, bersikap bersahabat, bersikap sopan, mau bekerja sama, serta memiliki rasa keingintahuan yang tinggi. Orang tua dapat menggunakan satu atau dua(campuran pola asuh) dalam situasi tertentu. Untuk membentuk anak agar menjadi anak yang berani menyampaikan pendapat sehingga memiliki ide-ide yang kreatif, berani dan juga jujur (Helmawati, 2016: 138-139).

Pengasuhan yang diberikan dan diterapkan oleh orangtua akan sangat mempengaruhi tumbuh kembang dan keberhasilan anak pada perkembangan selanjutnya, mulai dari kepribadian, mental, moral, sosial dan spiritualnya. Oleh sebab itu, peranan orang dewasa, yaitu orangtua sangat penting bagi perkembangan anak. Keberhasilan semua aspek perkembangan anak tersebut sangat bergantung pada lingkungan kehidupan anak. Yang pertama dan utama adalah lingkungan keluarga, kemudian sekolah dan masyarakat yang memberikan peran penting juga dalam pembentukan perilaku anak. Setiap keluarga memiliki pola asuh yang berbeda dalam mendidik seorang anak dan biasanya diturunkan oleh pola asuh yang diterima dari orang tua sebelumnya.

Macam-macam pola asuh orang tua mempengaruhi pembentukan kepribadian anak setelah ia menjadi dewasa. Hal ini dikarenakan ciriciri dan unsur-unsur watak seorang individu dewasa sebenarnya jauh sebelumnya benih-benihnya sudah ditanam tumbuhkan ke dalam jiwa seorang individu sejak awal, yaitu pada masa ia masih anak-anak. Artinya, perlakuan orang tua kepada anak-anaknya sejak masa kecil akan berdampak pada perkembangan sosial moralnya dimasa dewasa nya. Perkembangan sosial moral inilah yang akan membentuk watak 
sifat dan sikap anak kelak meskipun ada beberapa faktor lain yang berpengaruh dalam pembentukan sikap anak yang tercermin dalam karakter yang dimiliki anak.

\section{Pola Asuh Anak dalam Keluarga}

Pola asuh dapat dilihat dari sikap keluarga khususnya orang tua dalam kehidupan sehari-hari. Jika anak dibesarkan dengan rasa aman, ia belajar menaruh kepercayaan. Jika anak dibesarkan dengan dukungan, ia belajar menyenangi dirinya. Jika anak dibesarkan dengan kasih sayang dan persahabatan, ia belajar menemukan cinta dalam kehidupan (Jalaludin, 2001:103).

Pola asuh yang baik dan sikap positif lingkungan serta penerimaan masyarakat terhadap keberadaan anak akan menumbuhkan konsep diri positif bagi anak dalam menilai diri sendiri. Anak menilai dirinya sesuai dengan apa yang dialami dan didapatkan dari lingkungan. Anak dilatih untuk bersikap obyektif, dan menghargai diri sendiri dengan selalu berfikir positif untuk diri mereka sendiri (Hidayah, 2009: 16).

Dalam membentuk karakter bermoral pada anak sejak usia dini sangatlah penting Orang tua memberikan pengasuhan yang positif pada diri anak usia dini adalah dengan menanamkan hal-hal baik pada diri anak. Anak usia dini yang memiliki moral yang sejak dini (Wiyani, 2013: 90). Pada perilaku anak secara sadar dalam berperilaku beserta resiko yang harus dipertanggungjawabkan.

Anak mulai belajar dan meniru apa yang dilihatnya, terutama adalah perilaku orang tua sebab keluaga merupakan salah satu pembentuk karakter anak. Pengasuhan kelurga sangat penting bagi perkembangan anak. Dengan demikian anak harus diasuh dengan halhal yang baik, yaitu mulai dengan mengenalkan agama, mengajarkan disiplin, berperilaku jujur, suka menolong, dan hal-hal yang positif harus diajarkan orang tua kepada anak sedini mungkin . Hal tersebut dilakukan agar tertanam atau terinternalisasi dalam jiwa anak (Hurlock, 1978: 23).

Dalam kehidupan sehari-hari orang tua secara sadar atau tidak memberikan contoh yang kurang baik terhadap anaknya.misalnya meminta tolong dengan nada mengancam, tidak mau mendengarkan cerita anak tentang sesuatu hal, memberi nasihat tidak pada tempatnya dan tidak pada waktu yang tepat, berbicara kasar pada anak, terlalu mementingkan diri sendiri, tidak mau mengakui kesalahan yang telah dilakukan. Beberapa contoh sikap dan perilaku diatas berdampak negatif terhadap perkembangan jiwa anak. Sehingga dampaknya adalah anak memiliki sikap keras hati,manja, keras kepala, pemalas, pemalu dan lain- lain.

Semua perilaku diatas dipengaruhi oleh pola pendidikan orang tua. Pola asuh orang tua akan mempengaruhi perkembangan jiwa anak. Tipe kepemimpinan orang tua berdampak pada pola asuh yamg terhadap anaknya, disisi lain pola asuh orang tua bersifat demokratis atau otoriter, atau bahkan pada sisis lain bersifat laissez faire atau tipe campuran antara demokratis dan otoriter, (Syaiful, 2004).

Menurut Fadlillah (2012:35) bahwa lingkungan keluarga merupakan lingkungan awal bagi seorang anak, segala tingkah laku maupun 
perkembangan yang muncul pada diri anak akan mencontoh pada kedua orangtuanya. Selain itu, orangtua sebagai salah satu pihak yang bertanggung jawab dalam pendidikan sangat besar pengaruhnya terhadap perkembangan pendidikan anak. Orangtua dalam menjalankan perannya dalam pendidikan, perlu dengan terus-menerus untuk mendorong, membimbing, memotivasi dan memfasilitasi demi tercapainya pendidikan anak yang baik.

Anak dilatih untuk bersikap obyektif, dan menghargai diri sendiri dengan selalu berfikir positif untuk diri mereka sendiri (Hidayah, 2009: 16). Sikap orangtua ini meliputi cara orang tua memberikan aturanaturan, cara orang tua menunjukkan otoritasnya, dan cara orang tua memberikan perhatian serta tanggapan terhadap anaknya. Hal ini sangat penting bagi kehidupan anak karena perkembangan anak berawal dari pola asuh kedua orang tua.

Karakter seseorang berkembang berdasarkan potensi yang dibawanya sejak dari lahir, akan tetapi semakin berkembangnya seorang apalagi anak usia dini, perkmenbangan anak juga melibatkan peran dari orang tua yang mana dibutuhkan dalam membentuk perkembangan dari karakter seorang anak, bahwa pola asuh dari orang tua dapat mempengaruhi dan membentuk pribadi dari seorang anak secara signifikan (Hasanah, 2016). Peran penting dan pola asuh orang tua bagi perkembangan karakter anak usia dini sangat berpengaruh pada perkembangan aspek yang ada pada anak usia dini.

Peran orangtua merupakan perilaku yang berkenaan dengan orangtua dalam memegang posisi tertentu dalam lembaga keluarga yang didalamnya berfungsi sebagai pengasuh, pembimbing dan pendidik bagi anak. Pola asuh orang tua pada anak usia dini akan membentuk karakter ada anak, karenanya orang hendaknya memberikan stimulasi yang cukup bagi anak usia dini jikalau itu kurang akan mengakibatkan kemampuan sosialisi menjadi terlambat, maka dari itu lingkungan yang menunjang akan mendukung tumbuh kembang pada anak usia dini, proses pertumbuhan dan perkembangan seorang anak sangat pesat dan dapat berpengaruh bagi kehidupan selanjutnya. Anak pada masanya pembentukan biasanya akan di pengaruhi oleh lingkungan dalam membentuk karakter pada anak.

Beberapa hal yang perlu diperhatikan dalam pengasuhan anak adalah bahwa masa anak-anak merupakan masa penting dalam tahapan tumbuh kembang anak. Pertumbuhan dan perkembangan pada masa ini akan berpengaruh terhadap pertumbuhan dan perkembangan pada masa selanjutnya. Secara berturut-turut pertumbuhan fisik merupakan hal pertama yang perlu diperhatikan oleh sebab itu, orang tua perlu memastikan fisik anak berkembang dengan baik sesuai dengan tahap perkembangannya.

Perilaku baik atau buruk yang terjadi pada anak tergantung bagaimana orang dewasa dalam hal ini orang tua, pendidik dan orang di sekitar rumah dalam menerapkan serta memberikan simulasi yang baik serta patut ditiru oleh anak. Perilaku tersebut akan di bawa anak untuk menghadapi kehidupan selanjutnya, yaitu ketika anak masuk pada lingkungan masyarakat yang lebih luas dan ketika anak memasuki tahapan selanjutnya, sehingga akan melekat dan tertanam 
dalam kepribadian anak. Lingkungan masyarakat atau lingkungan diluar tempat tinggal anak adalah salah satu tempat keseharian yang dihabiskan oleh anak ketika anak sudah selesai dari aktivitas sekolah dan aktivitas di rumah.

Peran keluarga dalam pengasuhan anak sangatlah penting karena dapat mempengaruhi dan membentuk kepribadian atau karakter anak. Karakter anak tentu saja bergantung dari pola asuh orang tua terhadap anaknya. Keluarga juga mempunyai peranan dalam pengasuhan anak yaitu mengetahui tahap-tahap perkembangan anak untuk mengasuhnya sesuai dengan bakat dan keinginan anak. Namun, pola pengasuhan ayah dan ibu mempunyai perbedaan dan hal ini tidak membuat orang tua menjadi sulit dalam mengasuh anak, melainkan menjadi suatu hal untuk melengkapi kekurangan masing-masing dalam mengasuh anak.

\section{Kesimpulan}

Berdasarkan studi literature yang telah dilakukan dapat disimpulkan bahwa pola asuh orang tua terdapat dalam keluarga dan merupakan tanggung jawab utama kedua orang tua. Keluarga merupakan lembaga pertama dalam kehidupan anak, tempat anak belajar dan menyatakan diri sebagai makluk sosial. Keluarga yang memberikan dasar pembentukan tingkah laku, watak, moral, dan pendidikan bagi anak. Keluarga merupakan tempat pertama dan yang utama bagi anak untuk memperoleh pembinaan mental dan pembentukan kepribadian.

Orang tua yang memberikan penanaman nilai moral yang baik, akan menghasilkan anak yang memiliki kepribadian yang baik. Sebaliknya, orang tua yang memberikan penanaman nilai moral yang tidak baik, akan menghasilkan anak yang memiliki kepribadian yang buruk. Oleh karena itu walaupun pola pengasuhan setiap orang tua berbeda, orang tua tentunya mengharapkan yang terbaik untuk anaknya. Akan tetapi dari keempat macam pola asuh tersebut bentuk pola asuh demokrasilah pola asuh paling baik diterapkan oleh orang tua dalam mengasuh anak-anaknya karena pola asuh ini membentuk perilaku anak yang memiliki rasa percaya diri, bersikap bersahabat, bersikap sopan, mau bekerja sama, serta memiliki rasa keingintahuan yang tinggi. Oleh karena itu sangat penting peranan orang tua dalam mengasuh anak usia dini. Dengan mengerti berbagai pengetahuan dan informasi tentang pola pengasuhan yang ada maka orang tua dapat memberikan pengasuhan yang lebih baik kepada anak sehingga dapat meningkatkan pengembangan karakter disiplin pada anak-anak.

\section{Referensi}

\section{Journal article:}

Ayun, Qurrotu. 2017. Pola Asuh Orangtua dan Metode Pengasuhan dalam Membentuk Kepribadian Anak. Thufula : Jurnal Inovasi Pendidikan Guru Raudhatul Athfal. Vol.5, N0.1, JanuariJuniBrennan, M. A., \& Israel, G. D. (2008). The power of community. Community Development, 39(1), 82-97. 
Binus University. 2018. Pola Asuh Orang Tua dan Pengaruhnya pada Anak. Dari https://parent.binus.ac.id/2018/08/pola-asuh-orangtuadan-pengaruhnya-pada-anak/. Diakses tanggal 29 August 2018.

Muslimah, Jamiatul. 2020. Pola Asuh Orang Tua Dan Perkembangan Moral Anak Usia Dini (Studi Kasus di Tk Al-Ghazali Jl. Raya Nyalaran Kelurahan Kolpajung Kecamatan Pamekasan Kabupaten Pamekasan), Kiddo: Jurnal Pendidikan Islam Anak Usia Dini. Vol 1. No 1.

Latifah, Atik. 2020. Peran Lingkungan dan Pola Asuh Orang Tua terhadap Pembentukan Karakter Anak Usia Dini, JAPRA : Jurnal Pendidikan Raudhatul Athfal Volume 3, Nomor 2, September.

Novrinda, dkk. 2017. Peran Orang Tua dalam Pendidikan Anak Usia Dini di Tinjau dari Latar Belakang Pendidikan. Jurnal Potensia : PGPAUD FKIP UNIB, Vol. 2 No . 1.

Rakhmawati, Istina. 2015. Peran Keluarga dalam Pengasuhan Anak, Konseling Religi : Jurnal Bimbingan Konseling Islam Vol. 6, No. 1, Juni.

Sapani Tanjung, Pratiwi, dkk. 2020. Pengaruh Pola Komunikasi Verbal Orang Tua Terhadap Kemampuan Berbicara Anak Usia Dini. Jurnal Pendidikan Tambusai. 4(3), 3380-3386.

Syarifah, Hidayatus. 2017. Pendidikan dalam Keluarga, RAUDHAH Proud To Be Professionals Jurnal Tarbiyah Islamiyah Volume 2 Nomor 1, Juni.

Hasanah, U. 2016. Pola asuh orangtua dalam membentuk karakter anak. Elementary: Jurnal IImiah Pendidikan Dasar, 2(2), 72-82.

\section{Book:}

Fadlillah, Muhammad. 2012. Desain Pembelajaran Paud. Jogjakarta: Ar-Ruzz Media.

Helmawati. 2016. Pendidikan Keluarga. Bandung: PT. Remaja Rosdakarya.

Hidayah, Rifa. 2009. Psikologi Pengasuhan Anak. Malang: UIN-Malang Press.

Mariyana, dkk, 2010. Pengelolaan Lingkungan Belajar (Jakarta: Kencana Perdana Media Group.

Wiyani, Novan Ardy. 2013. Bina Karakter Anak Usia Dini, Jogjakarta:Ar-Ruzz Media.

Yulsyofriend. 2013. Permainan Membaca dan Menulis Anak Usia Dini. Padang: Sukabina Press

\section{Internet source}

Binus University. 2018. Pola Asuh Orang Tua dan Pengaruhnya pada Anak. Dari https://parent.binus.ac.id/2018/08/pola-asuh-orangtuadan-pengaruhnya-pada-anak/. Diakses tanggal 29 August 2018.

Junaidi, W. 2010. Macam-Macam Pola Asuh Orang Tua. Dari Http: www.blogspot.com. Diakses tanggal 22 Maret 2010. 